Krešimir Ivanda

Anđelko Akrap
Izvorni znanstveni članak

Rukopis je prihvaćen za tisak: 1. listopada 2020.

DOI: $10.21857 / 9 \mathrm{e} 31 \mathrm{lhv} 0 \mathrm{pm}$

\title{
STANOVNIŠTVO GRADA ZAGREBA NEPOSREDNO PRIJE I NAKON DRUGOGA SVJETSKOG RATA PREMA POTROŠAČKIM PRIJAVNICAMA
}

U radu se iznose procjene ukupnog broja stanovnika, dobno-spolnog sastava, struktura obitelji i kućanstva te strukture stanovništva prema ekonomskoj aktivnosti Grada Zagreba, sa stanjem u ožujku 1941. i u listopadu 1945. godine. Treba imati u vidu da 1941. godine nije bilo popisa stanovništva, pa je jedan od značajnijih istraživačkih rezultata ovog rada, uz ostale, i procjena ukupnog broja stanovnika i ekonomsko-socijalnih struktura u Gradu Zagrebu netom pred početak Drugoga svjetskog rata. Procjene su napravljene na osnovi izvornog arhivskog gradiva, koje obuhvaća oko 515 tisuća potrošačkih prijavnica (łv. potrošačkih kartica) pohranjenih u Državnom arhivu u Zagrebu. Za 1941. godinu procjene se temelje na potrošačkim prijavnicama za kućanstva, u kojima se nalazi popis svih članova kućanstva s osnovnim demografskim i ekonomsko-socijalnim obilježjima (oko 272 tisuće prijavnica). Procjena tematiziranih veličina u listopadu 1945. godine polazi od potrošačkih prijavnica za svaku osobu (oko 243 poimenične prijavnice), dakle ne više za kućanstva. Uz ostalo, dobno-spolnim sastavom predočena je jednostavna, vrlo jasna i sažeta demografska slika Grada Zagreba zabilježena na gotovo samom kraju Drugoga svjetskog rata.

Ključne riječi: stanovništvo Grada Zagreba; ekonomsko-socijalna struktura; struktura obitelji i kućanstava; ratom uvjetovana dobno-spolna struktura.

Ovaj je rad nastao kao dio istraživanja u sklopu znanstvenoistraživačkog projekta Kretanje broja stanownika i promjene ekonomsko-socijalne strukture Zagreba prema potrošačkim karticama od 1939. do 1947. godine (Ekonomski fakultet - Zagreb, voditelj istraživanja Anđelko Akrap). ${ }^{2}$ Rezultati dijela istraživanja bili su podloga za izradu doktorske disertacije Krešimira Ivande pod mentorstvom

\footnotetext{
1 U ovom se radu kao sinonim za potrošačke kartice pojavljuje i naziv potrošačke prijavnice.

2 Digitalizaciju arhivske građe iz Državnog arhiva u Zagrebu i prijepis dijela digitalizirane građe financijski su pomogli Grad Zagreb, Sveučilište u Zagrebu i Zaklada Adris.
} 
Anđelka Akrapa na Ekonomskom fakultetu Sveučilišta u Zagrebu. ${ }^{3}$ Prije svega, treba ukratko iznijeti cilj istraživanja u radu. U Hrvatskoj nakon popisa stanovništva 1931. godine nije bilo popisa sve do 1948. godine. Zbog Drugoga svjetskog rata, izostao je očekivani popis 1941. godine. Općepoznata je činjenica da je spomenuti rat nanio velike izravne i neizravne demografske gubitke. Isto je tako poznato kako za Grad Zagreb nisu raspoložive znanstveno utemeljene procjene, kako ni za onovremeni tako ni za sadašnji prostorni obuhvat, ukupnog broja stanovnika - ni za 1941. ni za 1945. godinu. S promjenom političko-gospodarskog sustava neposredno nakon spomenutog rata uslijedile su i značajne promjene $u$ ekonomsko-socijalnim strukturama stanovništva, stoga je od posebnog interesa istražiti/procijeniti ne samo ukupni broj stanovnika već i osnovne ekonomskosocijalne strukture stanovništva neposredno pred početak Drugoga svjetskog rata. Zato je cilj ovog rada napraviti znanstveno utemeljenu procjenu ukupnoga broja stanovnika Grada Zagreba za 1941. i 1945. godinu te procjenu ekonomskosocijalnih struktura. Kao metodološki utemeljen, pouzdan i sveobuhvatan izvor podataka za tematizirane procjene poslužile su potrošačke kartice (prijavnice) za Grad Zagreb u razdoblju 1939. - 1947. godine. O arhivskim izvorima i strukturi podataka obuhvaćenih potrošačkim karticama, kao i o metodologiji, opširnije će biti riječi u dijelu ovog rada pod naslovom Podaci i metodologija. No na samom početku navest ćemo zbog čega držimo spomenuti izvor podataka za procjene vrlo pouzdanim. U tom je pogledu najbitniji obuhvat stanovništva potrošačkim karticama. One su bile gotove u ožujku 1941., dakle prije početka rata, stoga nisu postojali politički razlozi za izbjegavanje te vrste evidencije. U tim je karticama svakom kućanstvu određena konkretna trgovačka radnja kao mjesto opskrbe osnovnim živežnim namirnicama. Razložno je pretpostaviti da je to jednostavno poticalo na prijavljivanje radi dobivanja isprave koja će omogućiti prehranu. To isto vrijedi i za potrošačke kartice iz listopada 1945. godine. Kartice iz ožujka 1941. evidentirale su "glavu kućanstva“ i sve članove kućanstva s osnovnim demografskim i socioekonomskim podatcima. Potrošačke kartice iz razdoblja 1945. - 1947. godine nisu se izdavale na razini kućanstava nego su bile poimenične. S određenom dozom opreza može se pretpostaviti da je, u odnosu na obuhvat u popisima stanovništva, obuhvat stanovništva potrošačkim karticama čak i veći zbog životno-egzistencijalne prinude $u$ ratnim vremenima i u vremenima neposredno nakon rata zbog nestašice.

Doktorski rad obranjen je u svibnju 2020. godine, a svi podaci korišteni u ovom radu rezultati su dijela istraživanja iz navedenog doktorskog rada. 


\section{UVOD}

Razvoj stanovništva nekog područja rezultanta je dugoročnih društvenih procesa i zbog toga je nužno zaći u analizu povijesnih okolnosti koje su prethodile razdoblju koje se istražuje u ovom radu. Suvremene karakteristike razvoja stanovništva ne mogu se razumjeti izvan konteksta povijesno-političkih, gospodarskih i demografskih međusobno povezanih procesa i zbivanja (WertheimerBaletić, 1993: 20). Zbog navedenog, opisat će se ključne povijesnodemografske prilike, promjene i okolnosti te će se dati kratak pregled povijesti Zagreba, s naglaskom na razdoblju od druge polovice 19. stoljeća do Drugoga svjetskog rata. U literaturi povijest Zagreba najčešće započinje činom osnutka biskupije (kraj 11. stoljeća) i nešto kasnijim stjecanjem naziva "slobodni kraljevski grad Zagreb” na temelju Zlatne bule (1242.). ${ }^{4} \mathrm{Od}$ samih početaka Zagreb privlači brojne doseljenike (najviše Nijemce i Talijane) te se u 15. stoljeću, u povoljnim razvojnim uvjetima, doseljavanje i intenzivira (Horvat, 1942; Krivošić, 1981). Međutim, nakon nekoliko stoljeća relativno stabilnog rasta, razvojni se trend mijenja i slijede gotovo dva stoljeća stagnacije, kako u demografskom, tako i u gospodarskom smislu. U 17. i 18. stoljeću ne bilježi se gotovo nikakav napredak u demografskom i gospodarskom smislu. Primjerice, sredinom 15. stoljeća Kaptol i Gradec zajedno su imali oko 4.500 stanovnika, dok je sredinom stoljeća na području povijesne jezgre današnjeg Zagreba bilo tek oko 3.600 stanovnika (Krivošić, 1981). Kako je od samih početaka Zagreb grad izrazito doseljeničkog karaktera, tako se demografski razvoj u 17. i 18. stoljeću veže uz prestanak doseljavanja ili čak i iseljavanje. Navedeno je glavni razlog demografskog zaostajanja jer je stanovništvo Zagreba u velikom dijelu srednjeg vijeka bilježilo prirodni pad i bilo je nužno održati kontinuitet doseljavanja kako bi se održao ukupni broj stanovnika u gradu (Krivošić, 1981). Ne samo da srednjovjekovni gradovi nisu bili samoreproducirajući entiteti - nego to zapravo do potkraj 19. stoljeća nije bio nijedan grad. Stope smrtnosti u urbanim središtima premašivale su natalitet, mortalitet novorođenčadi i siromašnih bio je osobito visok, pa su gradovi uvijek trebali migrante iz okolice (De Landa, 2002: 171). Naravno, prestanak doseljavanja treba promatrati u širem

\footnotetext{
$\overline{4}$ Već sama činjenica da je Zagreb bio sjedište katoličke biskupije davala mu je važnost još u doba srednjeg vijeka, kad je središte Hrvatskoga Kraljevstva bilo više na jugu i bliže moru. Uslijed čestih napada Mlečana i Turaka, centar Hrvatske tijekom povijesti se pomicao prema sjeveru i Zagreb je uslijed toga postajao sve više političkim centrom. Na Saboru koji se održao 7. 3. 1557. Zagreb se naziva metropolom Kraljevine Hrvatske, Dalmacije i Slavonije. U Zagrebu se vrlo često okupljaju Hrvatsko-slavonski sabor i Konferencija kraljevstva. Kad je Marija Terezija osnovala prvu Zemaljsku vladu kao kraljevsko vijeće, ona je poslije požara u Varaždinu 1. 7. 1776. prenesena u Zagreb, gdje je ostala do ukinuća 1779. (Peršić, 1935: 21). Centralne političke institucije tadašnje Hrvatske imale su kraće vrijeme sjedište u Varaždinu, prvenstveno zbog blizine nadređenom Beču, a i Požunu (Bratislavi), odnosno Budimu (Žuljić, 1981: 25).
} 
kontekstu povijesnih okolnosti na širem području i u drugim državama iz kojih su doseljenici dolazili. Osmanska osvajanja, ekonomske krize, zarazne bolesti i drugi nepovoljni faktori utjecali su na smanjenje broja doseljenika u Zagreb u navedenom razdoblju. Zbog svega navedenog, Hrvatska već od 15. stoljeća ne prati populacijske trendove u ostatku (razvijenijih) dijelova Europe (Akrap, 2012). Vrlo slično, Grad Zagreb od 16. stoljeća ne prati populacijske trendove kakve bilježe gradovi u ostatku (razvijenijih) dijelova Europe (Chandler, 1987; Krivošić, 1981; Mols, 1972). Neka istraživanja povezuju to razdoblje stagnacije i kaskanja kao glavni razlog „zakašnjelog razvoja kapitalizma”, koji je potom uzrok razvojnog kaskanja Zagreba i Hrvatske u cjelini za Europom (Bašić, 1994). Novi razvojni zamah Zagreb dobiva tek krajem 18. stoljeća, i to kombinacijom gospodarskog, demografskog i političkog razvoja (1776. postaje sjedištem hrvatske Vlade). To razdoblje opet karakterizira snažno doseljavanje iz inozemstva, pa je primjerice u drugom dijelu 18. stoljeća oko 31\% stanovništva bilo doseljeno iz inozemstva, i to pretežno iz srednje Europe: Nijemci, Talijani, Mađari, Česi, Austrijanci, Štajerci, Kranjci, Bavarci, Grci, Tirolci i ostali (Dobronić, 1972; Krivošić, 1981).

Razvoj Zagreba kao snažnog industrijskog centra i središnjega grada za ekonomski i društveni razvoj Hrvatske započinje u punoj mjeri sredinom 19. stoljeća, a često se simbolično označava ujedinjenjem Zagreba (Bašić, 1994; Krivošić, 1981; Nejašmić, 1994). Pod ujedinjenjem Zagreba smatra se čin spajanja triju općina 1850. godine: Gradeca, Kaptola i Vlaške Vesi - u literaturi je uvriježeno navoditi samo spajanje Gradeca i Kaptola, no i Vlaška je Ves od 1478. godine samostalna općina, ali pod utjecajem biskupa - iako su stanovnici sve tri općine i prije ujedinjenja nazivali Zagrebom (Peršić, 1935).

Druga polovica 19. stoljeća razdoblje je brze i sveobuhvatne industrijalizacije dotadašnje uglavnom manufakturne i obrtničke ekonomije u Zagrebu. Više je razloga zbog kojih je Zagreb postao središte industrijskog razvoja, od onih koji su šireg značaja, poput geografskog (prometnog) položaja ili političkog statusa, do onih koji su bliži praktičnim ekonomskim činiteljima razvoja, poput financijske snage. Naime, Zagreb je u drugoj polovici 19. stoljeća bio izrazito atraktivan poduzetnicima i industrijalcima zbog jednostavnog i stabilnog administrativnog i pravnog okvira osnivanja dioničkih društava te postojanja privatnog financiranja na području grada (Zagreb je bio "centar privatnog novčarstva” (Peršić, 1935)). Gospodarskom i demografskom usponu Zagreba pridonijelo je i razvojačenje Vojne krajine, koje je počelo 1872. godine, i smještanje administracije Zemaljske vlade u Zagrebu (Kolar-Dimitrijević, 1973: 12). Zagreb izgradnjom Zagorske željeznice 1886. godine dobiva bogat izvor jeftine radne snage za razvoj zanatstva i industrije. Usto, infrastruktura je bila na zadovoljavajućoj razini 
(dostupna i jeftina električna energija). Uz navedeno, ponuda radne snage i njezina struktura bila je ključna za gospodarski i industrijski razvoj. Naime, treba imati u vidu da je upravo to vrijeme početka demografske tranzicije u Hrvatskoj i zamjetnog porasta broja živorođenih, te iz godine u godinu sve većeg priljeva radne snage (Gelo, 1987). Osim toga, brza transformacija stanovništva po pitanju pismenosti u drugoj polovici 19. stoljeća ${ }^{5}$ pozitivno je djelovala na industrijalizaciju Zagreba (Peršić, 1935; Stipetić, 2013). Demografski pritisak iz okruženja i brz razvoj gospodarstva intenzivirao je doseljavanje u Zagreb; prema popisima stanovništva 1890., 1900. i 1910. godine, od ukupnoga broja stanovnika Zagreba oko 30\% rođeno je u Zagrebu, dok, prema popisu, 1931. godine taj udio pada na samo 25,3\% (Statistički godišnjak Zagreba, 1955). Brojna današnja poduzeća, raznih gospodarskih djelatnosti, osnovana su u razdoblju prvotne industrijalizacije u Zagrebu ${ }^{6}$, u 19. i na početku 20. stoljeća. Analitičke studije dijele razvojni put Zagreba na manufakturno-industrijsku fazu (drugi dio 19. stoljeća) i industrijsku fazu (od 1918. godine) (Majetić, 2015), a prateći popisne pokazatelje, može se smatrati kako od popisa 1931. industrija dominira u strukturi zanimanja stanovništva Grada Zagreba. Usporavanje u razvoju dolazi naglo u 1929. godini u povodu svjetske gospodarske krize, a i zbog izražene političke nestabilnosti u Kraljevini Jugoslaviji. Oporavak slijedi nekoliko godina kasnije, u drugom dijelu 1930-ih, ali naglo ga prekida početak Drugoga svjetskog rata (Bićanić, 1957; Majetić, 2015). Prema popisu iz 1857., Zagreb je u tadašnjem teritorijalnom obuhvatu imao 16.657 stanovnika. U današnjem teritorijalnom obuhvatu Grad Zagreb 1857. godine imao je 48.226 stanovnika ili 2,2\% od ukupnoga broja stanovnika Hrvatske. Spomenute je godine (1857.) Grad Zagreb imao, skupa s Požeško-slavonskom županijom, $u$ odnosu na sve druge županije (u današnjem teritorijalnom obuhvatu), najmanji udio u ukupnom stanovništvu Hrvatske (Akrap, 2012). Do 1931. godine broj je stanovnika Grada Zagreba porastao na 356.529, a udjel u ukupnom broju stanovnika Hrvatske porastao je na 6,8\%.

Teritorijalni obuhvat $u$ istraživanju važan je dio svake analize, a pogotovo je bitan za Grad Zagreb, koji je često mijenjao upravno-teritorijalni ustroj. Tijekom 19. i 20. stoljeća mijenjao je svoj upravno-teritorijalni obuhvat zbog širenja na nekada rubna područja, ali i zbog promjena upravno-teritorijalnog ustrojstva države. Nasuprot tome, administrativna promjena koja je posljedica brojnih reformi i upravno-teritorijalnih ustrojstava u vladama i državama koje su funkcionirale u 19. i 20.

\footnotetext{
5 Na razini Hrvatske i Slavonije (po tadašnjem teritorijalnom obuhvatu) u 30-ak godina razina nepismenosti smanjena je za gotovo 30 postotnih bodova (sa 77,9\% nepismenih 1880 . na 48,8\% 1910.).

6 O tome vidjeti detaljno istraživanju u: Ivanda (2020), Promjene u socioekonomskim obilježjima stanovništva Grada Zagreba, Sveučilište u Zagrebu, Ekonomski fakultet, doktorska disertacija.
} 
stoljeću uglavnom nije odražavala bitne promjene u demografskom razvoju koje bi zahtijevale širenje grada. Kao ilustraciju čestih promjena u upravno-teritorijalnom obuhvatu u 20. stoljeću valja istaknuti kako se obuhvat nije mijenjao samo između popisa 1900. - 1931. te između popisa 2001. - 2011. godine. Za potrebe ovog rada, važan je teritorijalni obuhvat 1931. - 1948. godine. U razdoblju 1900. - 1931. Grad Zagreb imao je površinu 64,37, a 1948. godine 74,99. Analize u ovom istraživanju koje se temelje na podacima s početka 1941. odgovaraju po obuhvatu popisu stanovništva iz 1931., odnosno obuhvaćaju površinu grada od 64,37. Analize koje se temelje na podacima iz 1945. godine odgovaraju obuhvatu s popisa stanovništva 1948., odnosno površini od 74,99. Glavna je razlika u proširenju grada koje je napravljeno u ljeto 1945. godine (14. 7. 1945.), kada su u obuhvat Grada Zagreba uključeni Bukovački breg i Kustošija te je grad u upravno-teritorijalnom smislu obuhvaćen nižim predstavničkim cjelinama naziva "narodni odbor", odnosno u teritorijalnom smislu podijeljen je na rajone (Ivanda, 2020).

\section{Podaci i metodologija}

Demografi se u svojim istraživanjima koriste brojim izvorima podataka, ali većinu informacija o populacijskim promjenama na lokalnoj razini te migracijama, u nedostatku popisnih podataka, daju administrativni i arhivski izvori podataka (Weeks, 2015). Popisi stanovništva u Hrvatskoj ustalili su se na desetogodišnjoj razini, ali u razdobljima političke i društvene nestabilnosti oko Drugoga svjetskog rata oni se nisu održali u „uobičajenim” intervalima. Kako je već istaknuto, posljednji popis prije Drugoga svjetskog rata proveden je 1931. godine, a prvi nakon njega 1948. godine. Taj popis 1948. godine bio je po opsegu popisnih pitanja, odnosno obilježja bitno kraći, odnosno jednostavniji, pa je prvi sljedeći, sveobuhvatniji popis proveden tek pet godina nakon njega, 1953. godine. U politički krajnje kriznom vremenu neposredno prije Drugoga svjetskog rata, kad je planiran, popis stanovništva nije proveden, stoga smo za razumijevanje društvenih i demografskih kretanja tog razdoblja posegnuli za drugim izvorima podataka.

U tu je svrhu digitalizirana (skeniranjem) arhivska građa tzv. potrošačke prijavnice (dalje u tekstu potrošačke prijavnice ili prijavnice). Potrošačke su prijavnice dokumenti (isprave) korišteni neposredno prije, tijekom i nakon Drugoga svjetskog rata u Zagrebu. Te su prijavnice pravno utemeljene u „Naredbi o raspodjeli (racioniranju) životnih namirnica“ koju je 27. siječnja 1941. izdala vlast Banovine Hrvatske. ${ }^{7}$ Za provedbu „Naredbe” bilo je zaduženo tijelo naziva

\footnotetext{
Naredba o raspodjeli (racioniranju) životnih namirnica od 27. siječnja 1941. od vlasti Banovine Hrvatske, otisnuta je na poleđini svake potrošačke prijavnice.
} 
„Ured za opskrbu Banovine Hrvatske“. Pozadina stvaranja i izvršenja takvog pravnog akta bila je kontrola potrošnje osnovnih životnih namirnica zbog društvene i ekonomske nestabilnosti i nesigurnosti pred početak Drugoga svjetskog rata na području Hrvatske. U literaturi se takva kontrola potrošnje naziva racionalizacija, odnosno racionalizirana potrošnja, a podrazumijeva kontroliranu distribuciju ograničenih resursa, proizvoda i usluga. To se najčešće odnosi na hranu, tekstil, gorivo, sirovine, lijekove, liječničku skrb i ostalo (Cox, 2013). Racionalizacijom se minimizira rizik od nestašice hrane koji je jedan od snažnih okidača socijalnih nemira, ali se postiže i optimalnija distribucija resursa između vojnog i civilnog sektora u ratnim uvjetima (Theien, 2009). Racionalizacija je $\mathrm{u}$ tom razdoblju bila prisutna u brojnim zemljama. Sjedinjene Američke Države i gotovo cijela Europa koristile su snažnu racionalizaciju čak i u razdoblju nakon Drugoga svjetskog rata (Cox, 2013).

Potrošačke prijavnice bile su jedan od glavnih elemenata racionalizirane potrošnje u Gradu Zagrebu. One zbog navedenog predstavljaju dobar izvor podataka koji ima obuhvat gotovo kao i popis stanovništva. Naime, potrošačke prijavnice bile su obavezne za čitavo civilno stanovništvo i dio vojnog stanovništva (one koji su živjeli u civilnim kućanstvima). Također, potrošačka prijavnica dolazila je s potrošačkim kuponima koji su bili nužni za kupovinu proizvoda koji su bili na listi za racionalizaciju (hrana, lijekovi i slično). Prema "Naredbi”, kućanstva su bila dužna prijaviti sve promjene u kućanstvu (povećanje i smanjenje broja članova i slično) u roku od tri dana.

Zbog svega navedenog, potrošačke prijavnice koristile su tri državne, odnosno gradske uprave u Gradu Zagrebu: Banovina Hrvatska, NDH i Federalna Država Hrvatska (Narodna Republika Hrvatska od 1946. godine), i to bez promjene formulara do kolovoza/rujna 1946. Nakon toga korišten je drugi tip prijavnice, $\mathrm{u}$ kojoj su ponešto izmijenjene varijable. Bitna je razlika u tome što se prijavnica izdaje za pojedinca, a ne za kućanstvo. Prijavnice sadrže osnovne demografske i socioekonomske pokazatelje na razini pojedinca i/ili kućanstva. Osim toga, moguće je izvesti i neke varijable koje izvorno nisu navedene (primjerice varijable obrazovanje ili socioekonomski status iz postojeće varijable zanimanje).

Izvorno arhivsko gradivo, potrošačke prijavnice (tzv. potrošačke kartice), pohranjene su u Državnom arhivu u Zagrebu, a obrađene su, odnosno digitalizirane u sljedećem obujmu:

- 271.551 skenirana isprava iz serije „Opskrbni odsjek”, tzv. potrošačke kartice za stanovnike Grada Zagreba 1941. - 1945. pohranjene u $621(62,1 \mathrm{~d} / \mathrm{m})$ kutiji;

- 243.199 skeniranih isprava iz serije HR - DAZG - 37.14.4.3. (37. Narodni odbor grada Zagreba, 14. Odjel za trgovinu i opskrbu, 4. Sektor opskrbe, 3. Evi- 
dencija izdanih potrošačkih karata i iskaznica za opskrbu) ukupne količine 144 kutije (od red. br. 226 do red. br. 369) tzv. potrošačke karte od 1945. nadalje.

Iz navedenog je jasno kako se radi o dvije različite vrste arhivske građe, odnosno dva tipa potrošačkih prijavnica. Naime, prvi tip potrošačkih prijavnica koristio se od siječnja 1941. godine do kolovoza/rujna 1945. godine. Drugi tip potrošačkih prijavnica koristio se od kolovoza/rujna 1945. nadalje. U kolovozu i rujnu 1945. godine preklapalo se korištenje obaju tipova potrošačkih prijavnica.

Do provedbe u uvodnom dijelu spomenutog projekta potrošačke prijavnice nisu bile digitalizirane.

Iako su sada sve potrošačke prijavnice digitalizirane, samo je dio njih prepisan u bazu podataka. Naime, potrebna su značajna financijska sredstva kako bi se digitalizirana građa prepisala u bazu podataka. Potrošačke prijavnice popunjavane su ručno, pisanim slovima i sadrže relativno brojne pogreške. Razni načini strojnog čitanja rezultirali su neuporabljivim bazama podataka zbog velikog broja pogrešaka. Ručno asistiranje strojnom čitanju, odnosno korigiranje pogrešaka iziskivalo bi dosta vremena i k tomu bi dalo upitne rezultate jer se pri čitanju potrošačkih prijavnica potrebno osloniti na vizualnu inspekciju svakoga pojedinog elementa prijavnice. Zbog navedenog, stvaranje baze podataka napravljeno je ručno, prijepisom podataka u računalo.

Korišten je slučajni uzorak od $79,72 \%$ svih potrošačkih prijavnica prvog tipa te obuhvaća 320.402 osobe. Također, korišten je i slučajni uzorak od 6,1\% potrošačkih prijavnica drugog tipa, odnosno 14.778 osoba. Varijable od interesa koje sadrži prvi tip prijavnice jesu: dob, spol, srodstvo unutar obitelji i kućanstva, zanimanje, vlasništvo nekretnine, broj djece u kućanstvu, živorođena djeca $\mathrm{u}$ kućanstvu za razdoblje u kojem prijavnica važi, povećanje i smanjenje broja članova kućanstva. Kod smanjenja broja članova kućanstva nije moguće razlučiti radi li se o smrti osobe ili selidbi jer na prijavnici nije zabilježena takva informacija već samo datum od kada navedena osoba više nije član kućanstva. Međutim, prijavnica sadrži datume prirasta, odnosno smanjenja broja članova kućanstva, što će biti važan dio kasnije analize i procjene ukupnog broja stanovnika.

Varijable od interesa koje sadrži drugi tip prijavnice jesu: dob, spol, mjesto rođenja, datum doseljenja u Zagreb, državljanstvo, narodnost, vjeroispovijest, zanimanje, poslodavac, mjesečni prihod (renta, plaća), bračno stanje. Većina varijabli odnosi se na pojedinca, ali nekoliko varijabli odnosi se na razinu kućanstva, pogotovo u prvom tipu prijavnica, a navedeno će se naglasiti u dijelu rada u kojem se analiziraju rezultati istraživanja.

Teritorijalni obuhvat $u$ radu sveden je na obuhvat usporediv s današnjim, $u$ dijelu rada u kojem se procjenjuje ukupni broj stanovnika. U ostalim analizama koristi se teritorijalni obuhvat koji je važio u razdoblju na koji se analiza odnosi. 


\section{Stanovništvo Grada Zagreba neposredno prije i nakon Drugoga svjetskog rata}

Prvo ćemo napraviti procjenu ukupnog broja stanovnika u Gradu Zagrebu neposredno prije i nakon Drugoga svjetskog rata. Suvremeni popisi stanovništva kao i drugi izvori podataka u demografiji često se temelje na konceptu kritičnog trenutka, odnosno nekog referentnog perioda za koji dane informacije vrijede. $\mathrm{U}$ tom kontekstu procjena ukupnog broja stanovnika u Gradu Zagrebu također je dana za dva kritična trenutka, odnosno datuma. Za spomenute potrošačke prijavnice prvog tipa kritični je trenutak 1. ožujka 1941. Za potrošačke prijavnice drugog tipa kritični je trenutak 1. listopada 1945. Nijedan od ta dva datuma nije odabran proizvoljno već su rezultat analize dinamike izdavanja novih potrošačkih prijavnica. Početak racionalizirane potrošnje u Zagrebu započinje 27. siječnja 1941., kada je donesen pravni okvir, a samo izdavanje potrošačkih prijavnica započelo je odmah, i to masovno, tako da su sva ili gotovo sva kućanstva imala potrošačku prijavnicu tijekom veljače 1941. godine. Sljedeći grafikon prikazuje dinamiku izdavanja novih potrošačkih prijavnica po mjesecima od siječnja 1941. do rujna 1945. godine (odnosi se samo na prijavnice prvog tipa).

Grafikon 1. Dinamika novoizdanih potrošačkih prijavnica po mjesecima u Gradu Zagrebu od siječnja 1941. do siječnja 1946.

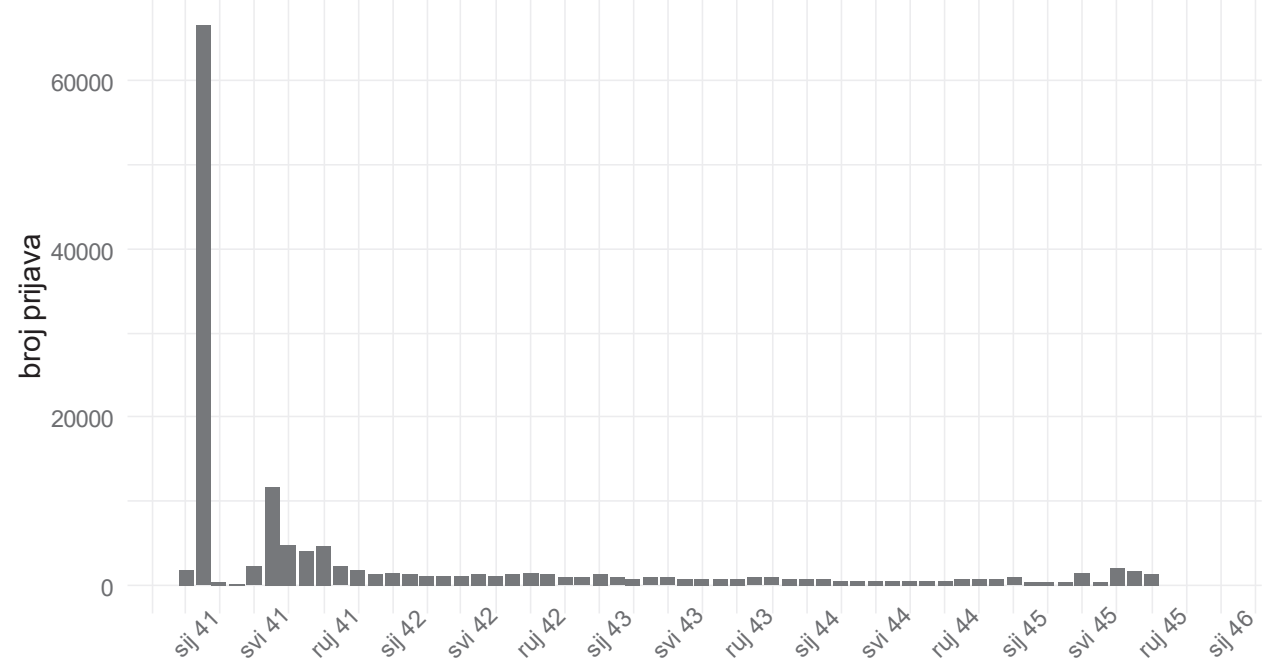

Izvor: obrada prema Ivanda (2020), potrošačke prijavnice prvog tipa 
U ožujku 1941. godine gotovo da i nema novoizdanih potrošačkih prijavnica, pa se pretpostavlja da su sva kućanstva dobila prijavnice u veljači 1941. godine. Zbog navedene dinamike izdavanja potrošačkih prijavnica, kao kritični trenutak za procjenu ukupnog broja stanovnika u Zagrebu iz prijavnica prvog tipa odabran je datum 1. ožujka 1941.

Tablica 1 daje procjenu broja stanovnika za oba kritična trenutka, odnosno oba tipa potrošačkih prijavnica, prema upravno-teritorijalnom obuhvatu u analiziranom razdoblju i onom koji vrijedi danas.

Tablica 1. Procjena ukupnog broja stanovnika u Gradu Zagrebu neposredno prije i nakon Drugoga svjetskog rata

\begin{tabular}{|l|c|c|}
\hline $\begin{array}{c}\text { Kritični trenutak / teritorijalni } \\
\text { obuhvat }\end{array}$ & Tadašnji obuhvat & Današnji obuhvat \\
\hline 1. ožujka 1941. & 224.550 & 312.200 \\
\hline 1. listopada 1945. & 243.100 & 310.100 \\
\hline
\end{tabular}

Izvor: obrada prema Ivanda (2020), potrošačke prijavnice prvog tipa

Prema potrošačkim prijavnicama prvog tipa, u kritičnom trenutku 1. ožujka 1941. procijenjeno je da je u Zagrebu živjelo oko 224.500 stanovnika, prema teritorijalnom obuhvatu koji je važio na taj datum. Procjena ukupnog broja stanovnika na dan 1. ožujka 1941. prema današnjem teritorijalnom obuhvatu iznosi 312.200 stanovnika. Procjena koja se odnosi na današnji teritorijalni obuhvat napravljena je množenjem koeficijenta, odnosa broja stanovnika tadašnjeg i sadašnjeg obuhvata prema popisu 1931. godine, s obzirom na to da je teritorijalni obuhvat 1. ožujka 1941. bio isti kao i u popisu stanovništva 1931. godine. Prema potrošačkim prijavnicama drugog tipa, na kritični trenutak 1. listopada 1945. procijenjeno je da je u Zagrebu živjelo oko 243.100 stanovnika prema teritorijalnom obuhvatu koji je važio na taj datum (on je u odnosu na obuhvat 1941. uvećan za područja Bukovački breg i Kustošiju, stoga nije izravno usporediv s procjenom broja stanovnika za 1941. godinu). Procjena ukupnog broja stanovnika na dan 1. listopada 1945. prema današnjem teritorijalnom obuhvatu iznosi oko 310.100 stanovnika.

Osim procjene broja stanovnika, napravljena je i analiza dobno-spolne strukture prema oba tipa prijavnica, odnosno u oba kritična trenutka. Sljedeći grafikon prikazuje dobno-spolnu strukturu na dan 1. ožujka 1941. 
Grafikon 2. Dobno-spolna struktura Grada Zagreba prema potrošačkim prijavnicama prvog tipa, 1. ožujka 1941.

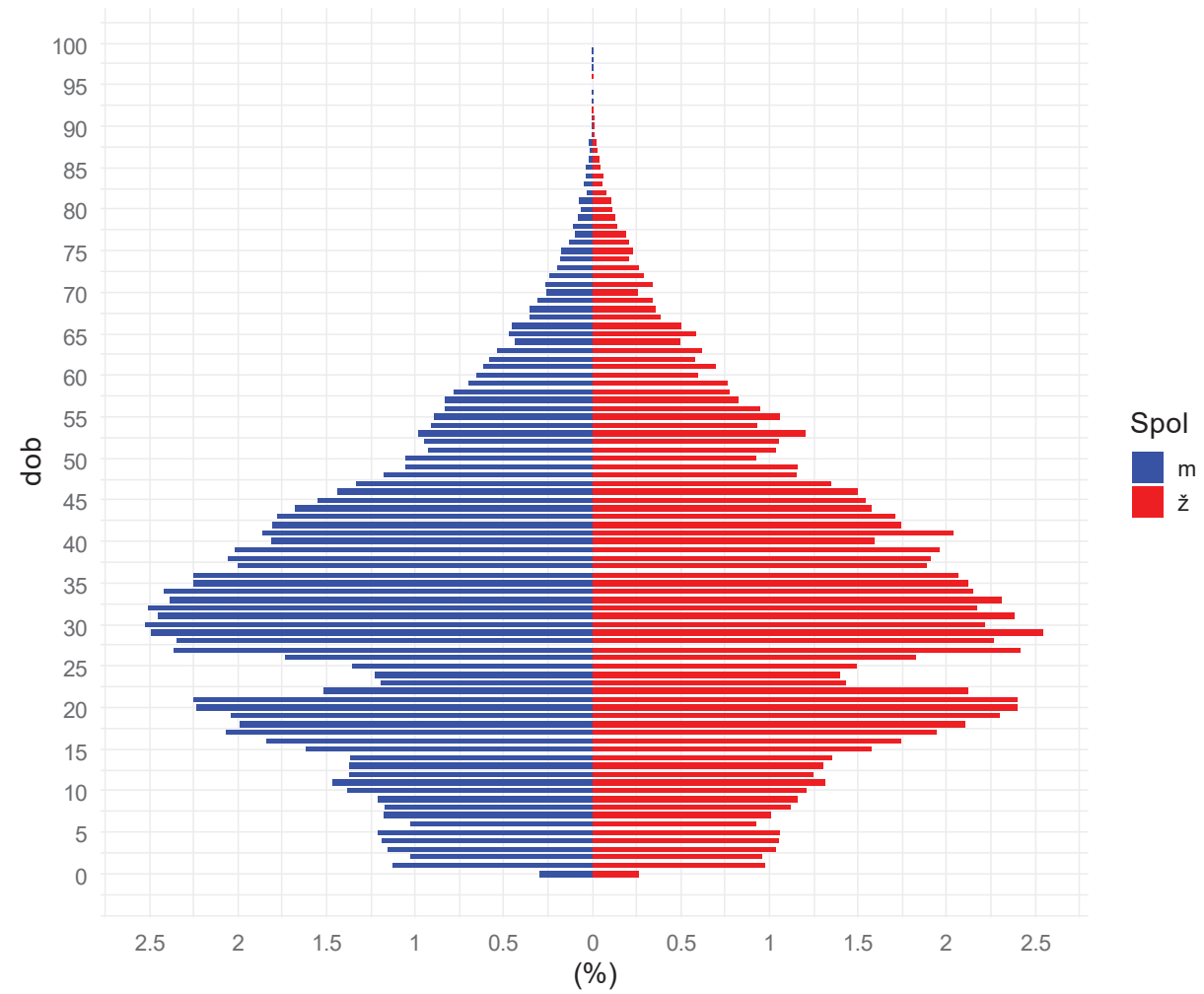

Izvor: obrada prema Ivanda (2020), potrošačke prijavnice prvog tipa

Dobno-spolna struktura Grada Zagreba 1. ožujka 1941., procijenjena na temelju potrošačkih prijavnica, pripada regresivnom tipu dobne strukture. Kada ne bismo poznavali činitelje koji su pridonijeli tako modificiranoj dobnoj strukturi, mogli bismo donijeti krivi zaključak kako je glavni razlog tome ubrzani pad nataliteta. Međutim, u ovom se slučaju radi o modificiranom tipu dobne strukture pod utjecajem migracije (Wertheimer-Baletić, 1999: 353). U dobnoj strukturi jasno se uočava jak utjecaj imigracije. Razvoj industrijskog sektora gospodarstva privukao je brojne useljenike. Vidljiva je i malobrojnija, tzv. krnja, generacija u dobi 20 - 25 godina, rođena tijekom Prvoga svjetskog rata. Uzimajući u obzir onovremene relativno visoke stope mortaliteta u svim dobnim skupinama, osobito muškaraca iznad 50 godina života, zbog jakih imigracija osoba u dobi iz- 
među 20 i 40 godina života u Grad Zagreb, apsolutno je i relativno mali udjel starijeg stanovništva. Prosječna dob u kritičnom trenutku 1. ožujka 1941. bila je 32,2, a medijalna 31 godinu. Žene su bile iznadprosječno zastupljene s oko 53,3\% u ukupnom stanovništvu (muškarci 46,7\%), što je novi fenomen. Do popisa 1931. godine muškarci su činili većinu u stanovništvu Zagreba, jer su među doseljenicima u Grad Zagreb na prijelazu iz 19. u 20. stoljeće uglavnom prevladavali muškarci. U međuratnom razdoblju, a pogotovo i nakon 1931. godine, započinje masovnije doseljavanje mladih žena u Zagreb, uglavnom iz zagrebačkog okruženja (Ivanda, 2020). Omjer između broja muškaraca i žena po petogodišnjim dobnim skupinama koristan je pokazatelj - on, između ostalog, pokazuje i masovno doseljavanje žena u Grad Zagreb. Tablica 2 pokazuje predratni omjer muškaraca i žena u Zagrebu (na dan 1. ožujka 1941.)

Tablica 2. Omjer muškaraca i žena u Gradu Zagrebu 1. ožujka 1941.

\begin{tabular}{|l|l|l|}
\hline Dobna skupina & Muškarci (\%) & Žene (\%) \\
\hline $0-4$ & 49,6 & 50,4 \\
\hline $5-9$ & 49,1 & 50,9 \\
\hline $10-14$ & 48,7 & 51,3 \\
\hline $15-19$ & 46,4 & 53,6 \\
\hline $20-24$ & 43,1 & 56,9 \\
\hline $25-29$ & 46,1 & 53,9 \\
\hline $30-34$ & 49,0 & 51,0 \\
\hline $35-39$ & 48,2 & 51,8 \\
\hline $40-44$ & 47,5 & 52,5 \\
\hline $45-49$ & 46,2 & 53,8 \\
\hline $50-54$ & 45,2 & 54,8 \\
\hline $55-59$ & 44,9 & 55,1 \\
\hline $60-64$ & 45,3 & 54,7 \\
\hline $65-69$ & 44,0 & 56,0 \\
\hline
\end{tabular}


Rad Hrvat. akad. znan. i umjet. Razred za druš. znan. 55=545(2021) : 1-29

\begin{tabular}{|l|l|l|}
\hline $70-74$ & 42,5 & 57,5 \\
\hline $75-79$ & 36,9 & 63,1 \\
\hline $80-84$ & 35,3 & 64,7 \\
\hline $85+$ & 36,0 & 64,0 \\
\hline
\end{tabular}

Izvor: obrada prema Ivanda (2020), potrošačke prijavnice prvog tipa

S obzirom na gospodarski razvoj Grada Zagreba od zadnjih desetljeća 19. stoljeća do 1941. godine, predočeni omjer muškaraca i žena po petogodišnjim dobnim skupinama očekivan je i odgovara glavnim obilježjima dobne strukture stanovništva tijekom velikih imigracija. U tumačenje dobno-spolne strukture stanovništva treba uključiti i očekivani duži životni vijek žena te višu smrtnost muškaraca u svim dobnim skupinama, osobito dojenčadi i onih u dobi iznad 50. godine života.

U nizu istraživačkih rezultata u ovom radu svakako je najzanimljivija dobno-spolna struktura Grada Zagreba na grafikonu 2 koja je formirana iz potrošačkih prijavnica drugog tipa na dan 1. listopada 1945. Ona pokazuje tipična obilježja dobne strukture nastale nakon velikih gubitaka stanovništva tijekom rata. Predočena je jednostavna, vrlo jasna i sažeta demografska slika Grada Zagreba zabilježena na samom kraju Drugoga svjetskog rata. Vide se dio izravnih i neizravnih demografskih gubitaka nastalih tijekom Drugoga svjetskog rata. Međutim, manji broj osoba u dobnoj skupini 20 - 24 godine može biti stoga što je iz te dobne skupine bilo najmasovnije vojačenje i neposredno nakon rata. Ipak, to ne može objasniti tako velik utor u toj dobnoj skupini. Rat sa svojim posljedicama izaziva ne samo velike kratkoročne gubitke već i dugoročne duboke poremećaje u svim komponentama razvoja stanovništva (Wertheimer-Baletić, 1993: 207). Općenito se u razmatranjima o demografskim gubitcima u Hrvatskoj nastalim tijekom Drugoga svjetskog rata i u neposrednom poraću susrećemo s jednom od najkontroverznijih tema. Potpuniji osvrt na tu vrlo osjetljivu i složenu temu prelazi okvire ovog rada. 
Grafikon 2a. Dobno-spolna struktura Grada Zagreba prema potrošačkim prijavnicama prvog tipa, 1. listopada 1945.

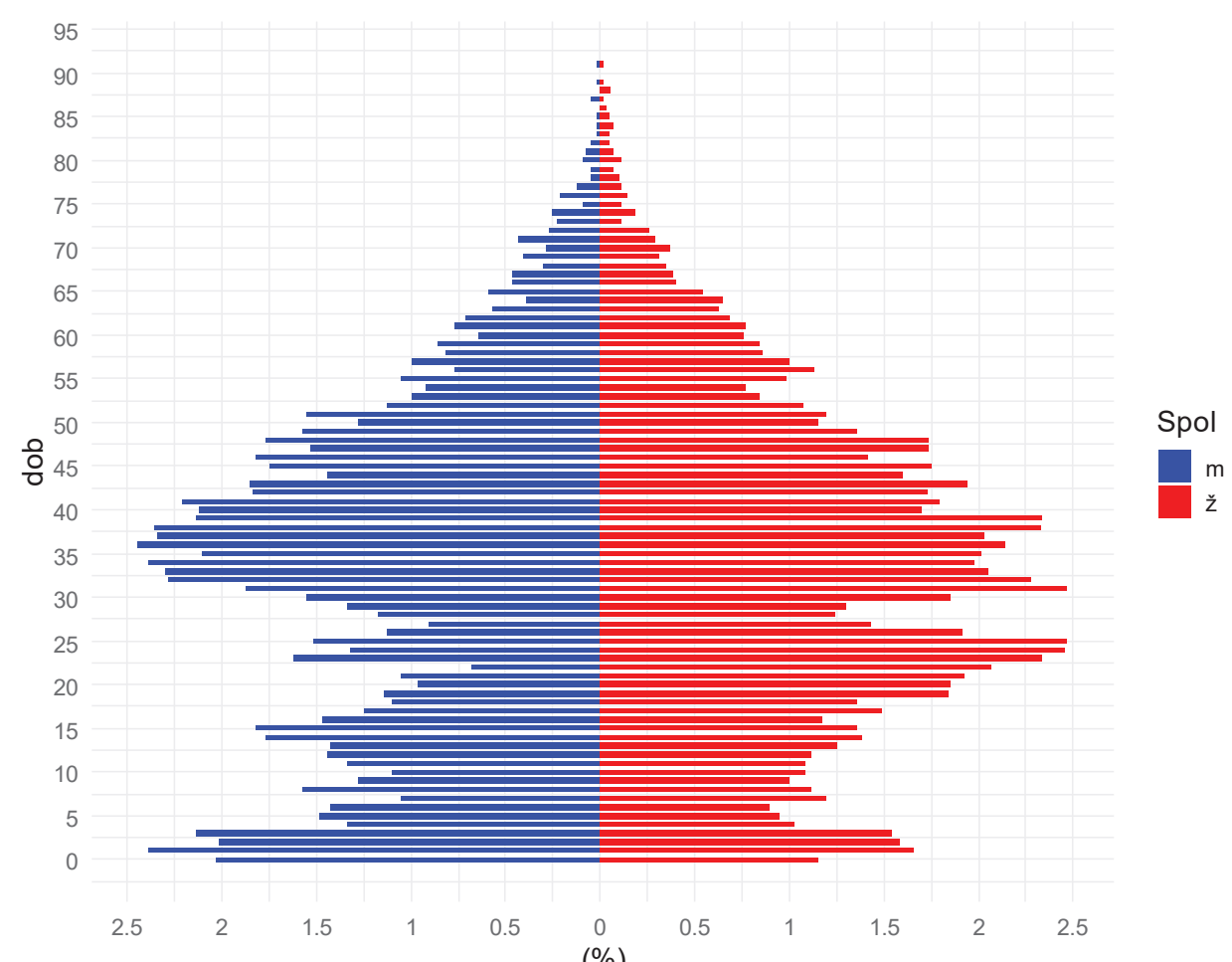

Izvor: obrada prema Ivanda (2020), potrošačke prijavnice drugog tipa

Disbalans između petogodišnjih dobnih skupina po spolu pokazuje i tablica 2. Krnje generacije (malobrojne generacije koje značajno odstupaju u veličini u odnosu na susjedne kohorte po dobi) jasna su posljedica Drugoga svjetskog rata, i to posebno kod muškaraca u mlađoj dobi (20. - 30. godine života). Dobno-spolna struktura prikazuje i jednu neočekivanu izdvojenicu, a to je značajno veći broj muške djece u prve dvije godine života (bitno viši od biološki uvjetovanog većeg broja živorođene muške djece). Moglo bi se pretpostaviti da je ta razlika nastala zbog eventualne sistemske pogreške pri upisivanju spola živorođenih, ali tako brojne greške gotovo su nemoguće. Tumačenje te pojave moglo bi se povezati s tradicijom osiguravanja obiteljske loze po muškom djetetu. Stoga se osobito u uvjetima nestašice i u životno neizvjesnim vremenima veća skrb vodila o muškoj djeci. Iako nije provedeno sustavno istraživanje, možemo, s dozom 
opreza, dati objašnjenje toj pojavi na temelju razgovora s 10-ak osoba rođenih $\mathrm{u}$ Gradu Zagrebu 1930-ih godina. Prema njihovim izjavama, nije bila masovna, ali ni rijetka pojava da Zagrepčani koji su imali veći broj djece smjeste žensku djecu $\mathrm{k}$ roditeljima ili bliskoj rodbini u selima u širem zagrebačkom okruženju.

Tablica 3. Omjer muškaraca i žena u Gradu Zagrebu 1. listopada 1945.

\begin{tabular}{|c|c|c|}
\hline Dobna skupina & Muškarci (\%) & Žene $(\%)$ \\
\hline $0-4$ & 53,3 & 46,7 \\
\hline $5-9$ & 51,4 & 48,6 \\
\hline $10-14$ & 48,9 & 51,1 \\
\hline $15-19$ & 42,9 & 57,1 \\
\hline $20-24$ & 29,8 & 70,2 \\
\hline $25-29$ & 36,8 & 63,2 \\
\hline $30-34$ & 43,9 & 56,1 \\
\hline $35-39$ & 45,6 & 54,4 \\
\hline $40-44$ & 46,4 & 53,6 \\
\hline $45-49$ & 45,7 & 54,3 \\
\hline $50-54$ & 48,3 & 51,7 \\
\hline $55-59$ & 42,8 & 57,2 \\
\hline $60-64$ & 41,5 & 58,5 \\
\hline $65-69$ & 47,3 & 52,7 \\
\hline $70-74$ & 49,1 & 50,9 \\
\hline $75-79$ & 44,1 & 55,9 \\
\hline $80-84$ & 36,8 & 63,2 \\
\hline $85+$ & 30 & 70 \\
\hline
\end{tabular}

Izvor: obrada prema Ivanda (2020), potrošačke prijavnice drugog tipa 
Ključno je istaknuti činjenicu prema kojoj je predratni omjer muškaraca i žena bio na strani većeg udjela ženskog stanovništva u svim dobnim skupinama. No neposredno nakon Drugoga svjetskog rata omjer jasno pokazuje značajan gubitak muškog stanovništva u mlađim dobnim skupinama. Tako je primjerice udio muškaraca u čitavoj dobnoj skupini 20 - 24 manji od $30 \%$. To je važno istaknuti jer to pokazuje razmjere stradavanja najvitalnijeg muškog stanovništva. Već smo naveli, dio objašnjenja može se naći i u činjenici da je iz te dobne skupine i nakon rata bilo najviše uvojačenih.

Neravnoteža u dobnim skupinama između broja muškaraca i žena u središnjoj ženidbeno-udadbenoj dobi, pa i u preostalim mlađim dobnim skupinama, utjecala je na manji broj brakova i, u skladu s time, rezultirala i manjim natalitetom. Neravnoteža u omjeru muškaraca i žena vidljiva je u cijelom kontingentu u dobi 15 - 45 godina. Ratna stradanja vojnog i civilnog osoblja te iseljavanja i progoni u bitnome su pojačali postojeću predratnu neravnotežu muškog i ženskog stanovništva.

\section{Struktura obitelji i kućanstava}

Struktura obitelji i kućanstava povezana je s društvenim i ekonomskim razvojem Grada Zagreba. Intenzivno doseljavanje u Grad Zagreb kroz cijelu prvu polovicu 20. stoljeća odrazilo se i na demografske pokazatelje i proces formiranja obitelji i kućanstava. Jedan od glavnih pokazatelja utjecaja doseljavanja u Zagreb jest distribucija broja članova po kućanstvu prikazana u grafikonu 3.

Grafikon 3. Broj članova po kućanstvu u Gradu Zagrebu 1. ožujka 1941.

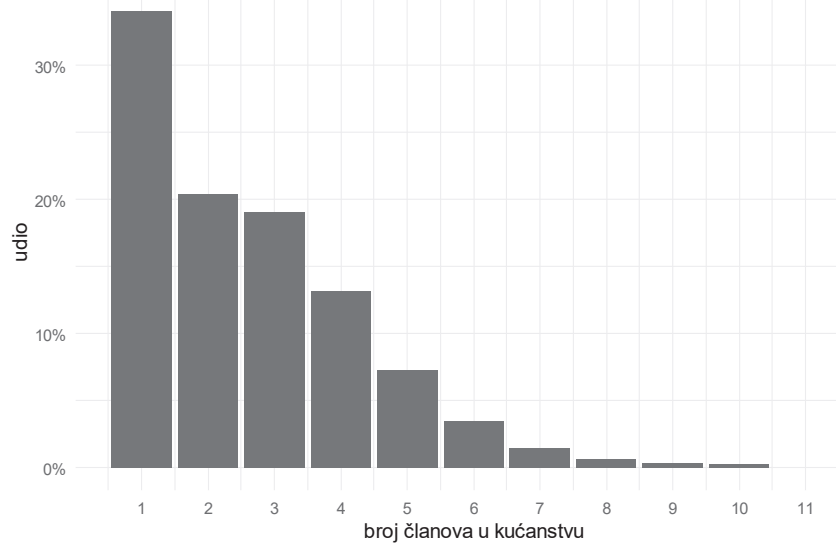

Izvor: obrada prema Ivanda (2020), potrošačke prijavnice prvog tipa 
Cjelokupna distribucija prema broju članova u kućanstvima u predratnom Zagrebu jasno upućuje na relativno malu veličinu prosječnog kućanstava u tadašnjem razdoblju - prosječno kućanstvo brojilo je tek 2,63 člana. Zagreb u predratnom razdoblju (ožujak 1941.) bilježi relativno visok udio samačkih kućanstava, oko 34\%, što je dijelom posljedica snažnog doseljavanja u dvadesetim i tridesetim godinama 20. stoljeća. Tada je većina doseljenika bila iz neposredne okolice Zagreba u mlađoj životnoj dobi te uglavnom još nisu formirali vlastite obitelji u Zagrebu. Ujedno je to razdoblje u kojem se ubrzano širi industrijska mreža i povećava broj zaposlenih $\mathrm{u}$ industriji, što je povezano s promjenama u obiteljskim strukturama u smjeru kasnijeg zasnivanja obitelji i kućanstvima s manjim brojem članova. Samačka kućanstva relativno su nova pojava koja je pratila industrijalizaciju, a neki su od glavnih činitelja porasta samačkih kućanstava, između ostalog, rast očekivanog trajanja života, kasnija dob ulaska u prvi brak, prihvaćanje samostalnog života žena, kvalitetnija briga i zdravstveni uvjeti starijeg stanovništva, bolji financijski položaj, odnosno ekonomsko blagostanje starijeg stanovništva (Kreider i Vespa, 2014).

Na temelju popisa stanovništva iz 1931. može se izračunati da je prosječna veličina kućanstva u Gradu Zagrebu iznosila 4,2 člana, a prema popisu iz 1948. godine 2,5 članova (Ivanda, 2020). Značajan pad prosječne veličine kućanstva zbio se već prije Drugoga svjetskog rata, kad je pala na 2,63 člana početkom 1941. godine. U razdoblju 1953. - 2001. godine prosječna veličina kućanstva stagnira i kreće se u rasponu 2,8 - 2,9 članova da bi prema popisu iz 2011. godine pala na 2,6 članova po kućanstvu. Kolebanja u prosječnoj veličini kućanstava u Gradu Zagrebu, osim s transformacijama u obiteljskim strukturama, treba povezati i s većim ili manjim priljevom doseljenika, što je uvjetovano ritmovima društveno-gospodarskog razvoja. Uočava se i razlika po spolu, žene u prosjeku žive u većim kućanstvima u odnosu na muškarce. Dodatno, udio muškaraca koji žive u samačkim kućanstvima iznosio je oko 16\%, a udio žena koje žive u samačkim kućanstvima oko 10\%. Takav obrazac većeg udjela samačkih kućanstava među muškarcima iščezao je do popisa 1991. godine, kada većinu samačkih kućanstava čine žene, za što je uglavnom zaslužno duže očekivano trajanje života, pa je veći udio samačkih kućanstva kod starijeg ženskog stanovništva. Kada obiteljska kućanstva definiramo kao kućanstva koja mogu uključivati samo djecu, roditelje i praroditelje te isključimo samačka kućanstva, tada u Gradu Zagrebu na početku 1941. godine bilježimo oko 56,2\% obiteljskih i 43,8\% neobiteljskih kućanstava (Ivanda, 2020).

Potrošačke prijavnice drugog tipa (listopad 1945.) sadrže podatke o bračnom stanju pojedinca. $S$ obzirom na visok mortalitet osoba starih 65 i više godina i 
prosječnu dob ulaska u brak mlađih osoba, ovdje je analiza svedena na dobnu skupinu 20 - 64 godine. U tom kontekstu grafikon 4 predočava distribuciju četiriju glavnih tipova bračnog stanja definiranih kao u prijavnicama. Nepoznata opažanja izuzeta su iz analize, a u najmlađim analiziranim dobnim skupinama $(20$ - 24 i 25 - 29) ona su bila značajna (11,3\% i 5,5\%). U preostalim dobnim skupinama zanemariv je udio nepoznatih opažanja. Vjerojatni razlog navedenom jest ostavljanje prazne rubrike kod mlađih, što je pretpostavljalo da "nije u braku“, ali oni se $u$ analizi nisu pribrojili toj kategoriji već su isključeni iz analize.

Grafikon 4. Bračno stanje u Gradu Zagrebu po petogodišnjim dobnim skupinama, listopad 1945.

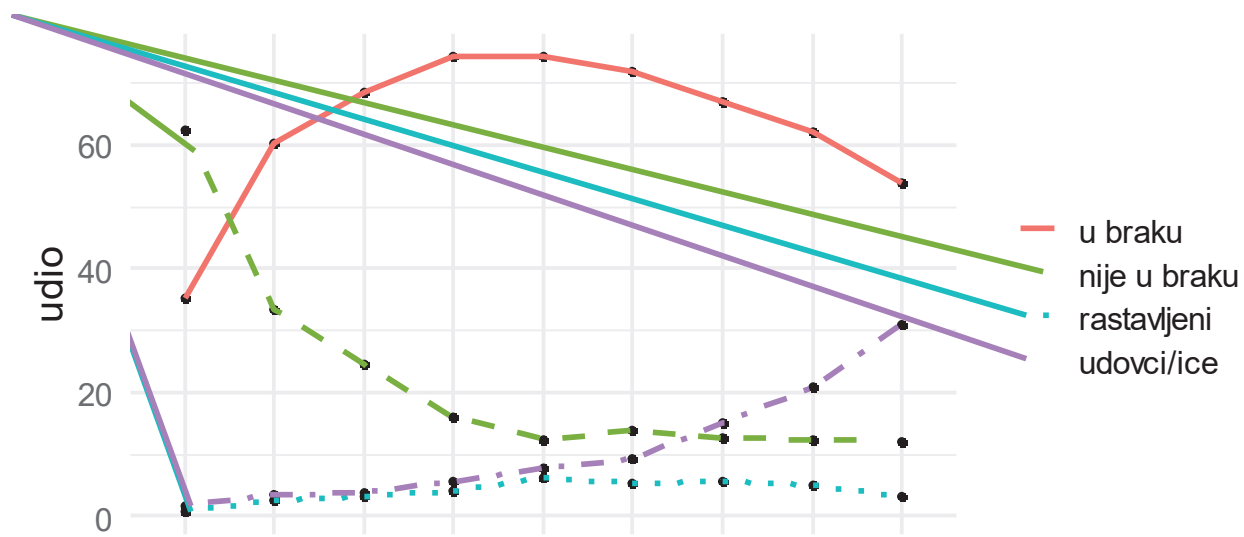

20-24 25-29 30-34 35-39 40-44 45-49 50-54 55-59 60-64 dobna_skupina

Izvor: obrada prema Ivanda (2020), potrošačke prijavnice drugog tipa

Prema petogodišnjim dobnim skupinama, jasno se očituje nekoliko trendova, a sve krivulje imaju očekivani oblik: rast broja udovaca(ica) u starijim dobnim skupinama i rast broja onih u braku u kasnim dvadesetim i ranim tridesetim godinama. Brak je dominantan oblik obiteljskog aranžmana, a najveći udio ima u dobnoj skupini 35 - 39 godina, gdje je $74,3 \%$ svih osoba poznatog bračnog stanja bilo u braku. Kod najmlađe analizirane dobne skupine oko $35 \%$ stanovnika jest u braku, a 62,5\% nije u braku. Udio rastavljenih (6,1\%) najviši je u dobnoj skupini $40-44$ godine. Udio osoba u braku i rastavljenih pada od dobne skupine $45-49$ godina zbog rasta udjela udovica ili udovaca, a takvih je u dobnoj skupini $60-64$ godine oko $31 \%$. 
Zaključno, brak postaje dominantan oblik „bračnog stanja“, odnosno obiteljskog aranžmana od dobne skupine 25 - 29 godina i nadalje. Udio udovica/udovaca ima snažnu pozitivnu korelaciju s dobi, dok udio rastavljenih prati oblik krivulje onih u braku, ali s nižim vrijednostima. Pomnija analiza distribucije stanovništva Grada Zagreba prema bračnom stanju, zabilježena neposredno nakon Drugoga svjetskog rata, razvidno pokazuje posljedice rata: za ono je vrijeme relativno velik udio neoženjenih/neudanih u dobnim skupinama do 35 godina te razmjerno značajan broj udovica u mlađim dobnim skupinama. I ovdje se, dakle, očituju ratom uvjetovani poremećaji u sastavu stanovništva Grada Zagreba prema bračnom stanju.

\section{Struktura stanovništva Grada Zagreba prema ekonomskoj aktivnosti 1941. i 1945. godine}

Cjelokupni društveni život, od biološke reprodukcije do proizvodnje i najsloženijih socijalnih procesa i transformacija, umnogome je uvjetovan ekonomsko-socijalnim strukturama stanovništva (Wertheimer-Baletić, 1978: 21). Shodno tomu, razmotrit ćemo i strukturu stanovništva prema ekonomskoj aktivnosti. Na samom početku razmatranja o aktivnosti treba imati u vidu da je nemoguće oblikovati usporedivu dugu vremensku seriju podataka o ekonomskoj aktivnosti, posebno prema zanimanjima. Što je postignuti stupanj gospodarskog razvoja viši, to su i ekonomsko-socijalne strukture složenije jer se širi broj zanimanja i djelatnosti. Stoga je i usporedivost podataka u vremenskom kontekstu ograničena. Izravne usporedbe podataka dobivenih u popisima od druge polovice 20 . stoljeća do danas nisu moguće i zbog potpuno različite popisne metodologije i definicija pojedinih pojmova. Prema tome, čak i u razdoblju nakon Drugoga svjetskog rata, u kojem je postignuto više desetljeća kontinuiteta u kontekstu vlasti i sustava, nije ostvaren kontinuitet $\mathrm{u}$ usporedivosti podataka zbog čestih izmjena administrativno-teritorijalnog ustrojstva države, promjena u popisnoj metodologiji, definiciji ekonomske aktivnosti, klasifikaciji zanimanja i ostalim činiteljima koji smanjuju ili onemogućuju usporedivost podataka i rezultata istraživanja. $\mathrm{U}$ tom kontekstu rezultate ovog istraživanja treba promatrati $u$ okviru razdoblja koje se istražuje i izbjegavati usporedbu s drugim vremenskim serijama ili današnjom perspektivom. Uz sva navedena ograničenja, ekonomska aktivnost i zanimanja često su najbolji pokazatelj razine ljudskog kapitala na nekom području, pogotovo u povijesnim retrospektivama. Primjer je otežane ili gotovo nemoguće usporedivosti podataka s drugim vremenskim serijama informacija o zanimanjima na temelju potrošačkih prijavnica. U potrošačkim prijavnicama prvog tipa (onima iz 1941.) zabilježena su čak 14.864 različita (je- 
dinstvena) zanimanja. ${ }^{8}$ Naravno, u stvarnosti nije postojala takva diversifikacija rada već je uzrok navedenog činjenica da su osobe, najčešće glave kućanstva, upisivale vrstu zanimanja po vlastitom nahođenju. Tako je primjerice zanimanje „domar" pisano još i kao „kućepazitelj”, „podvornik” i brojnim drugim nazivima (neka raširena zanimanja imala su i po 20 -ak različitih naziva). U takvom slučaju nužna je klasifikacija zanimanja prema većim skupinama te je ona i provedena na način da su vrlo slična i srodna zanimanja svedena pod isti naziv. Standardna klasifikacija koja se koristi u literaturi je ISCO klasifikacija zanimanja. Za istraživanja povijesnih populacija često se koristi derivacija ISCO klasifikacije zanimanja naziva HISCO, koja sadrži 1.881 kategoriju zanimanja koja su postojala u drugoj polovici 19. i početkom 20. stoljeća (Maas $i$ sur., 2002).

Glavni čimbenik otežane usporedivosti ekonomske aktivnosti u istraživanjima koja se bave razdobljem prije Drugoga svjetskog rata, a ponekad i u onima do 1960-ih, jest poljoprivredno stanovništvo. Naime, poljoprivredno stanovništvo u popisima stanovništva i u drugim izvorima podataka često je arbitrarno popisivano od strane samih popisivača ili stanovništva (Wertheimer-Baletić, 1978). Tako primjerice ekonomska aktivnost u razdoblju između 1870. i 1910. ima raspon od čak 16 postotnih bodova među popisima. U stvarnosti su takve varijacije nemoguće jer nije bilo tako snažnih promjena u strukturi zaposlenosti. Općenito su u Hrvatskoj sve donedavno posebno mjesto u problematici klasifikacije poljoprivrednog stanovništva imale žene (Akrap, 1996). Naime, definicija poljoprivrednog stanovništva nije bila jednoznačna te su često popisivač ili popisivana osoba procjenjivali pripada li aktivnom poljoprivrednom kontingentu, a to se ponajviše ogleda kod žena u ruralnim područjima koje su dio dana bile kućanice, a dio dana pomažući članovi u poljoprivrednim gospodarstvima. U takvim okvirima popisivanje je provođeno arbitrarno, odnosno prisutna je snažna subjektivnost popisivača pri ocjeni je li žena pretežno kućanica ili aktivan radnik u poljoprivredi. Zbog svega navedenog, rezultati između ranijih popisa stanovništva po pitanju ekonomske aktivnosti, bez dodatnih svođenja na razinu usporedivosti, gotovo su potpuno neusporedivi (Ivanda, 2020; Stipetić, 2013; Wertheimer-Baletić, 1978; 1999). Popis stanovništva iz 1931. godine također daje relativno oskudne i neusporedive pokazatelje ekonomske aktivnosti. Zbog navedenog, ekonomsku aktivnost prikazujemo iz potrošačkih prijavnica. Čak i u ovom slučaju, prijavnice iz 1941. i one iz 1945. nisu potpuno usporedive ponajviše zbog šireg obuhvata neaktivnog stanovništva 1945. Ipak, usporedivost je donekle moguća s obzirom na to da je provedena klasifikacija zanimanja na

S obzirom na to da je obrađen, tj. digitaliziran uzorak od 79,72\% svih prijavnica prvog tipa, ukupni skup potrošačkih prijavnica iz 1941. godine sadrži i veći broj jedinstvenih zanimanja. 
veće skupine zanimanja te se mlado i staro stanovništvo relativno jednostavno identificira iz podataka u potrošačkim prijavnicama. Tablica 4 prikazuje sastav stanovništva Grada Zagreba prema ekonomskoj aktivnosti neposredno prije i po završetku Drugoga svjetskog rata.

Tablica 4. Stanovništva Grada Zagreba prema ekonomskoj aktivnosti 1941. i 1945. godine

\begin{tabular}{|l|c|c|}
\hline Kategorija aktivnosti & $\begin{array}{c}\text { Udio u ukupnom stanovništvu (\%) } \\
\text { 1. ožujka 1941. }\end{array}$ & $\begin{array}{c}\text { Udio u ukupnom stanovništvu } \\
\text { (\%) 1. listopada /10/1945. }\end{array}$ \\
\hline Mladi (15 i manje) & 16,61 & 20,38 \\
\hline Nezaposleni & 4,64 & 3,82 \\
\hline Zaposleni & 49,52 & 41,63 \\
\hline Neaktivni & 24,68 & 29,81 \\
\hline Stari $(65+)$ & 4,55 & 4,36 \\
\hline
\end{tabular}

Izvor: obrada prema Ivanda (2020), potrošačke prijavnice prvog i drugog tipa

U oba promatrana razdoblja udio starijih, u dobi 65 i više godina, nizak je (manji od 5\%), a udio mladih relativno je visok. Udio neaktivnih (prema pretpostavkama analize, to su svi oni koji nisu zaposleni ni eksplicitno nezaposleni, ali su u dobi 15 - 64) jest visok u oba analizirana razdoblja, dok je udio nezaposlenih nizak. Ipak, navedene kategorije ne možemo uspoređivati s današnjim definicijama nezaposlenih i neaktivnih osoba.

Jasan je vidljiv rast udjela stanovništva mlađeg od 15 godina. Razlog tome nije značajan rast broja rođenih ili doseljavanje izbjegle djece tijekom rata već pad apsolutnog i relativnog broja stanovništva u dobi 20 - 30 godina koje predstavlja dobnu skupinu najviše pogođenu ratnim stradanjima.

Dodatno je razmotrena ekonomska aktivnost i prema dobi i spolu, s obzirom na to da su izračunate specifične stope ekonomske prema spomenutim obilježjima. Grafikon 3 predočava specifične stope ekonomske aktivnosti po dobi i spolu za stanovništvo Zagreba u ožujku 1941. godine. 
Grafikon 5. Specifične stope ekonomske aktivnosti po dobi i spolu u Gradu Zagrebu, ožujak 1941.

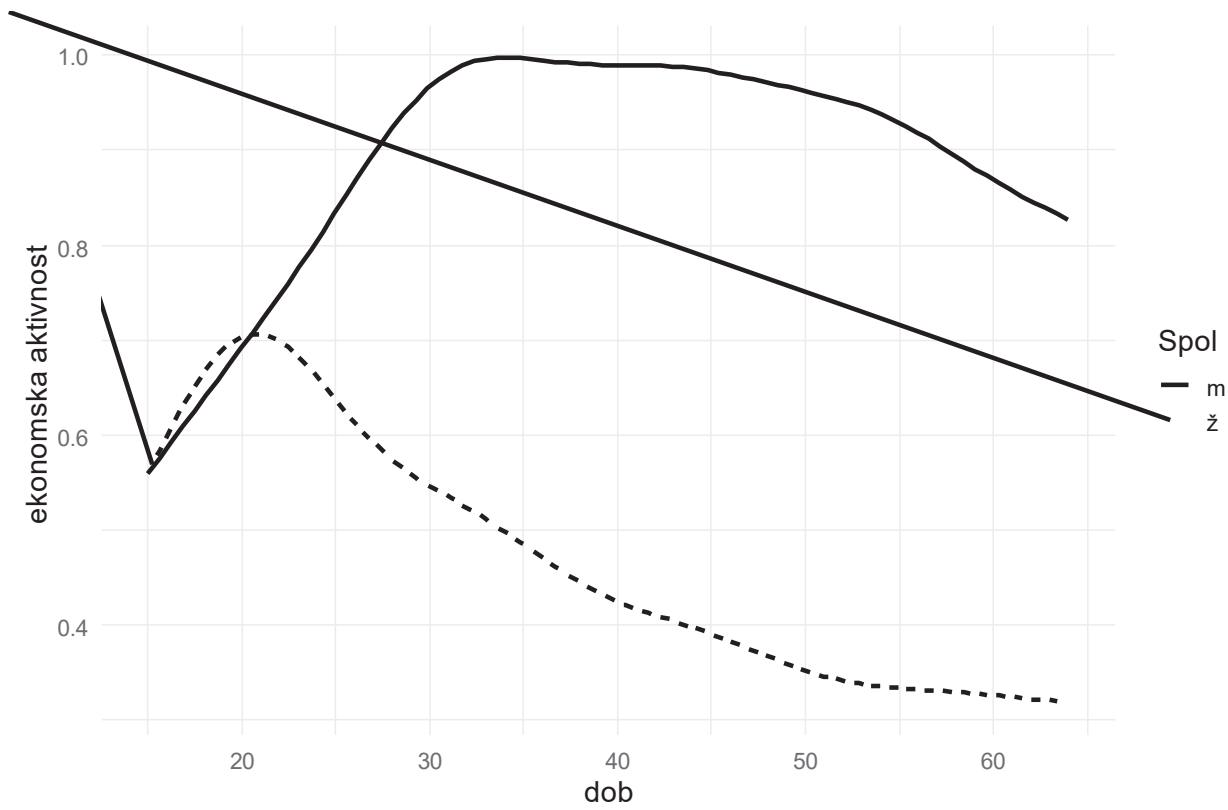

Izvor: obrada prema Ivanda (2020), potrošačke prijavnice prvog i drugog tipa

Specifične stope aktivnosti po dobi i spolu daju jasan deskriptivni uvid u razliku između ekonomske aktivnosti žena i muškaraca u predratnom Gradu Zagrebu. Sama razlika u aktivnosti prema dobi i spolu daje i jednostavniji uvid u strukturu gospodarstva i distribuciju zanimanja u stanovništvu. Specifična stopa aktivnosti za muškarce ima očekivanu krivulju - visoke razine aktivnosti u središnjem dijelu radnoaktivne dobi, odnosno 30. - 50. godine koji prati postupan pad. Vrijednosti specifičnih stopa aktivnosti za muškarce u dobi 30 - 50 godina izrazito su visoke, u rasponu 90 - 9. ${ }^{9}$ Nasuprot tome, specifične stope aktivnosti žena razmjerno su niske u svim dobnim skupinama osim kod onih mlađih od 20 godina koje su usporedive ili čak i više nego kod muškaraca. Vjerojatni razlog tomu jest rano zapošljavanje mladih žena kao kućnih pomoćnica, što je bio rasprostranjen oblik osamostaljivanja mladih žena u predratnom Zagrebu.

9 Takve su razine aktivnosti uobičajene za to doba i očekivane. Stope aktivnosti i u 21. su stoljeću u Zagrebu za tu dob jednako visoke, a ukupna stopa ekonomske aktivnosti prelazi 85\% (Ivanda, 2020.). 
Naime, doseljavanje u Zagreb, pogotovo mladih žena iz neposredne okolice, bilo je dosta rašireno u međuratnom razdoblju.

Grafikon 6. Ekonomska aktivnost stanovništva Grada Zagreba po spolu i po rajonima, listopad 1945.

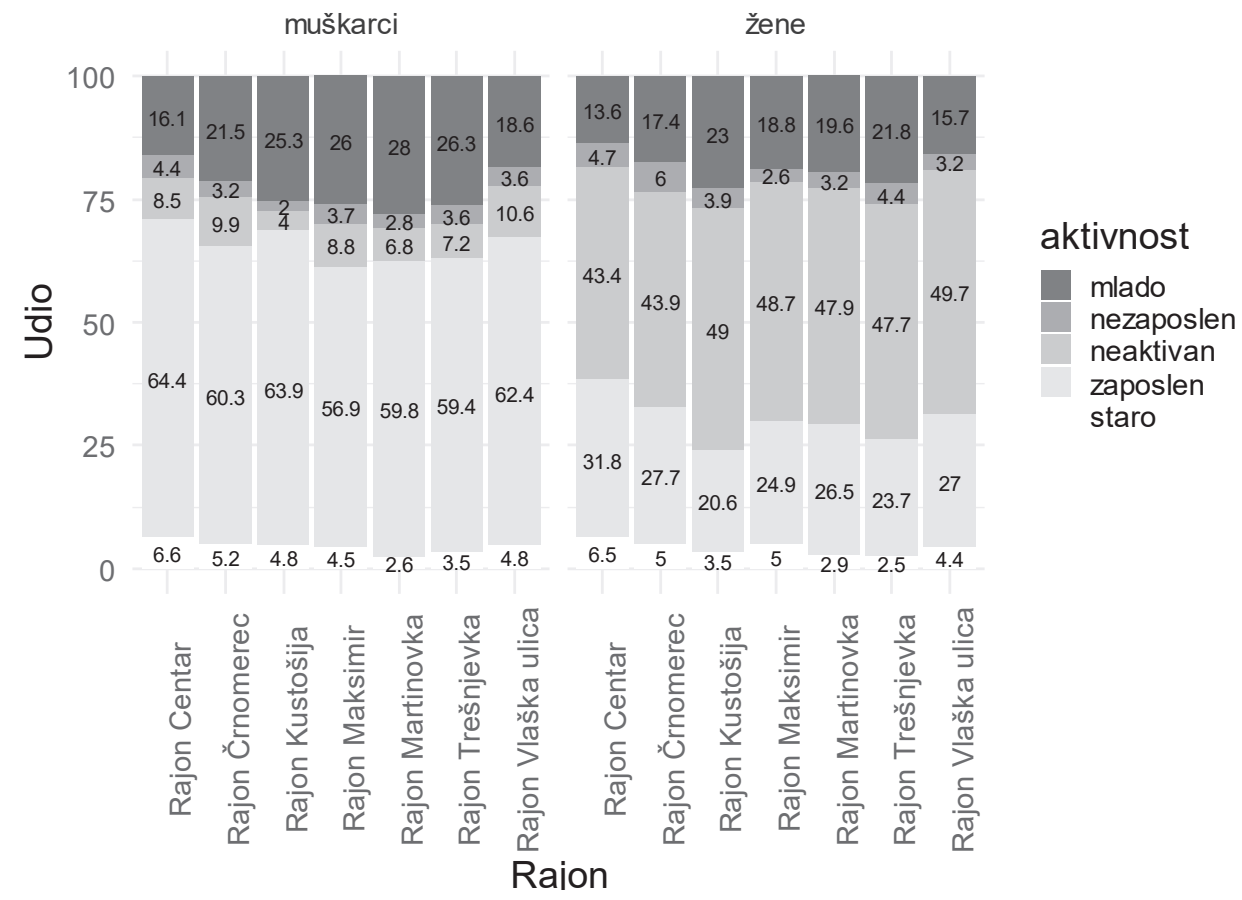

Izvor: obrada prema Ivanda (2020), potrošačke prijavnice drugog tipa

Postupno slabljenje poljoprivrede kao glavne gospodarske grane u zagrebačkom okruženju stvorilo je "višak" žena koje nisu lako nalazile poslove u industriji i manufakturnom sektoru gospodarstva. U takvim prilikama značajan je broj mladih žena našao posao kao kućne pomoćnice. Navedeno nije specifičnost Zagreba već i ostalih europskih gradova (Čapo-Žmegač, 1996; Ivanda, 2020; Szabo, 1984). Čak i uz rašireni model kućanske pomoćnice, nezaposlenost žena na početku 20. stoljeća bila je visoka (Szabo, 1984). Kroz cijelo 20. stoljeće ekonomska je aktivnost žena rasla, pa je i očekivano da mlađe kohorte žena imaju više razine ekonomske aktivnosti od starijih kohorti. Iako je nezaposlenost i neaktivnost žena relativno visoka, valja napomenuti kako je u analiziranom razdoblju još uvijek prevladavao model muškog hranitelja. Iako je krivulja izglađena u 
odnosu na izvorne podatke, nije bilo naglog izlaska s tržišta rada nakon 50. ili 55. godine života radi prijevremenog umirovljenja, što se prakticiralo od 1960ih sve do danas (Akrap i sur., 2018; Družić, 1989). Grafikon 6 pokazuje detaljnu distribuciju ekonomske aktivnosti po spolu u čitavom Gradu Zagrebu i po nižim administrativnim jedinicama tog doba - rajonima (listopad 1945.). Razlike u ekonomskoj aktivnosti između muškaraca i žena prisutne su i nakon rata. Takav prikaz još bolje pokazuje u kojem se kontingentu nalazi manjak aktivnih žena - u skupini ekonomski neaktivnih. Naime, većina neaktivnih žena navela je zanimanje kao kućanice. Razlike između nižih administrativnih jedinica također su prisutne. Primjerice, kod muškaraca raspon stope zaposlenosti relativno je visokih 7,5 postotnih bodova, a kod žena 11,2 postotnih bodova između rajona. Pri tumačenju diferenciranih značajki stopa ekonomske aktivnosti treba uzeti u obzir i, iz grafikona 6, očiglednu razliku u dobnim strukturama stanovništva između onovremenih administrativnih jedinica - rajona.

Zaključno, ekonomska aktivnost stanovništva Grada Zagreba u razdoblju oko Drugoga svjetskog rata relativno je visoka, ali sa značajnom varijacijom po spolu: muškarci bilježe vrlo visoke stope aktivnosti, i to u čitavoj radnoaktivnoj dobi, dok je kod žena ekonomska aktivnost razmjerno niska u cijeloj radnoaktivnoj dobi, osim kod najmlađe kohorte žena, one u dobi 15 - 20 godina života.

\section{Umjesto zaključka}

Prva polovica 20. stoljeća posebno je važna u razvoju stanovništva Grada Zagreba. Na početku 20. stoljeća grad je prolazio kroz snažnu industrijalizaciju i transformaciju gospodarstva. Razvoj industrije i popratni modernizacijski procesi u samom gradu, ali i u ostatku Hrvatske, odigrali su ključnu ulogu u promjenama socioekonomskih obilježja stanovništva. Industrijalizacija je, prema istraživačkim rezultatima ovog rada, $\mathrm{u}$ bitnome utjecala na demografske procese. Intenzivno doseljavanje iz neposrednog okruženja Grada Zagreba na početku 20. stoljeća rezultiralo je brzim promjenama ekonomske aktivnosti stanovništva po zanimanjima i promjenama u strukturama obitelji i kućanstava. Mali gradovi u okruženju Grada Zagreba samo su manjim dijelom mogli prihvatiti radnu snagu koja se odlijevala iz agrarnog sektora gospodarstva. U takvim se uvjetima u Grad Zagreb slijevalo obilje radne snage. Doseljavanje žena iz okolice Zagreba, koje su u poljoprivrednim i ruralnim sredinama uslijed industrijalizacije i modernizacije postale „višak" na lokalnom tržištu rada, utjecalo je na povećanje dostupne radne snage u Zagrebu u vrlo kratkom periodu. Uz navedeno, intenzivno doseljavanje rezultiralo je rastom udjela mladog stanovništva u Zagrebu, a time i porastom broja samačkih kućanstava - uz „očekivani“ udio 
samačkih kućanstava, on se povećao i s mladim doseljenicima koji još nisu formirali svoje obitelji i kućanstva. Osim navedenog, mlade žene koje su se doseljavale u Zagreb u velikom su broju pronalazile i ekonomsku neovisnost, odnosno prvi posao kao kućne pomoćnice. Tadašnji Zagreb, jednako kao i drugi gradovi u Europi, imao je raširenu pojavu „kućnih pomoćnica“, što je predstavljalo uobičajeni model ekonomskog osamostaljivanja mladih žena. Potrošačke prijavnice koje su korištene u radu kao glavni izvor podataka vrlo su vrijedan arhivski izvor podataka. Takvi izvori podataka predstavljaju vrijedne i, nerijetko, jedine izvore podataka. S obzirom na turbulentnu povijest vezanu uz razdoblje Drugoga svjetskog rata i neprovođenje očekivanog popisa stanovništva u ustaljenom desetogodišnjem razdoblju (1941.), potrošačke prijavnice važan su i jedini izvor podataka te daju informacije na individualnoj razini za gotovo cijelo stanovništvo Grada Zagreba. Tako su nam prijavnice, među ostalim, omogućile procjenu ukupnog broja stanovnika u Zagrebu za kritični trenutak 1. ožujka 1941. (224.500 po tadašnjem teritorijalnom obuhvatu) i 1. listopada 1945. (243.100 po tadašnjem teritorijalnom obuhvatu). Dobno-spolna struktura stanovništva Grada Zagreba u predratnom Zagrebu već pokazuje znakove sužavanja baze, iako je udio starih nizak (ispod 5\%). Doseljavanje je povećalo udio mladih, ali demografski su trendovi bili jasni: pad broja živorođenih, smanjenje veličine kućanstava i općenito povećanje svih indikatora demografskog starenja. Ratna zbivanja jasno se ogledaju u dobno-spolnoj strukturi stanovništva Grada Zagreba - posebno je narušen odnos muškaraca i žena u mlađim dobnim skupinama (20 - 34) kao i apsolutni i relativni gubitak stanovništva u toj dobi. Opet treba imati u vidu da je dio iz prethodno spomenute dobne skupine uvojačen u poraću. Pokazatelji obiteljskih aranžmana, poput udjela osoba u braku, izvan braka, razvedenih i udovaca/ica daju očekivane rezultate - brak je najvažniji oblik obiteljskog aranžmana i prikazuje očekivanu krivulju po dobnim skupinama isto kao i udio rastavljenih, ali s nižim apsolutnim vrijednostima. Udovci/ice snažno su pozitivno korelirani s dobi, što je i očekivano, čak i uz utjecaj Drugoga svjetskog rata. Naime, stanovništvo koje je najviše zahvaćeno ratnim stradanjima jest mlado stanovništvo u dobi 20 - 34 godine, pa se zato iz te dobne skupine bilježi mali udio $\mathrm{u}$ bračnom statusu. Posljedica navedenog jest i mali udio udovaca/ica $u$ toj dobnoj skupini. Ekonomska aktivnost bila je relativno visoka, ali je prisutna jasna diskrepancija po spolu - žene su imale nisku ekonomsku aktivnost u svim dobnim skupinama, s izuzetkom najmlađe analizirane dobne skupine, za koju je karakterističan već spomenuti model kućne pomoćnice.

Konačno, analizirano razdoblje predstavlja vrlo dinamičan dio povijesti Grada Zagreba. Za potrebe ovog rada iskorišten je samo dio podataka/informacija 
izvornog arhivskog gradiva koji se može dobiti iz potrošačkih prijavnica. Procijenjene su demografske i ekonomsko-socijalne strukture stanovništva Grada Zagreba na izvorima podataka dobivenim iz potrošačkih kartica iz 1941. i 1945. godine. Buduća istraživanja ove teme mogu nadograditi istraživačke rezultate ovog rada detaljnijim analizama; ponajprije naglašeno specifičnih političkih, društvenih, gospodarskih i demografskih čimbenika u Gradu Zagrebu u razdoblju neposredno prije, tijekom i nakon Drugoga svjetskog rata. Dobno-spolnim sastavom predočena je jednostavna, vrlo jasna i sažeta demografska slika Grada Zagreba zabilježena na samom kraju Drugoga svjetskog rata. Vidi se dio izravnih i neizravnih demografskih gubitaka nastalih tijekom Drugoga svjetskog rata. Jedna od budućih vrlo zanimljivih istraživačkih tema, na temelju potrošačkih prijavnica 1941. - 1945., jest analiza utjecaja migracije na demografske promjene u Gradu Zagreba tijekom Drugoga svjetskog rata i u neposrednom poraću. Zabilježene migracije u potrošačkim karticama osvjetljavaju migracijska strujanja bitna ne samo za Grad Zagreb već i za čitavu Hrvatsku i države u okruženju. 
Rad Hrvat. akad. znan. i umjet. Razred za druš. znan. 55=545(2021) : 1-29

\section{Literatura}

Akrap, A. (1996), Determinante regionalnih promjena ekonomski aktivnog stanovništva

Republike Hrvatske (upravno-teritorijalna podjela po županijama). Doktorska disertacija. Sveučilište u Zagrebu, Ekonomski fakultet.

Akrap, A. (2012), Demografska putanja u Hrvatskoj, Hrvatska revija, (1-2): 4-25.

Akrap, A., Strmota, M., i Ivanda, K. (2018), Ekonomska aktivnost stanovništva u

Hrvatskoj u dobi od 55 do 64 godine i potencijalne rezerve radne snage, U: EFZG

Occasional Publications (Katedra za makroekonomiju). Ekonomski fakultet, Sveučilište u Zagrebu, str. 3-22.

Bašić, K. (1994), Socijalno-prostorna segregacija stanovništva Zagreba, Geografski horizont, 40(2), str. 73-78.

Bićanić, R. (1957), Razvoj industrije u Zagrebu, u: Iz starog i novog Zagreba. Zagreb: Izdanja muzeja grada Zagreba (1), str. 266-277.

Čapo-Žmegač, J. (1996), Konstrukcija modela obitelji u Europi i povijest obitelji u Hrvatskoj, Narodna umjetnost: hrvatski časopis za etnologiju i folkloristiku, 33(2), str. 179-196.

Chandler, T. (1987), Four Thousand Years of Urban Growth: An Historical Census. Revised edition. Lewiston, N.Y., U.S.A: Edwin Mellen Pr.

Cox, S. (2013), Any Way You Slice It: The Past, Present, and Future of Rationing. New York: The New Press.

De Landa, M. (2002), Tisuću godina nelinearne povijesti. Zagreb: Naklada Jesenski i Turk.

Dobronić, L. (1972), Zagrebački građani prije dvije stotina godina, Kaj: časopis za kulturu i prosvjetu, V(7-8), str. 3-13.

Družić, I. (1989), Interakcija ekonomskog sistema i sistema mirovinskog osiguranja,

U: Suvremeni ekonomski problemi. Zagreb: JAZU i Informator, str. 123-159.

Gelo, J. (1987), Demografske promjene u Hrvatskoj u razdoblju od 1780. do 1981. godine. Zagreb: Globus.

Horvat, R. (1942), Zagreb: povijest hrvatskoga glavnog grada. Zagreb: Hrvatsko književno društvo Sv. Jeronima.

Ivanda, K. (2020), Promjene u socioekonomskim obilježjima stanovništva Grada Zagreba. Doktorska disertacija. Sveučilište u Zagrebu, Ekonomski fakultet.

Kolar-Dimitrijević, M. (1973), Radni slojevi Zagreba od 1918 - 1931. Zagreb: Institut za historiju radničkog pokreta Hrvatske.

Kreider, R., i Vespa, J. (2014), The Historic Rise of One-Person Households: 1850-2010, U: SEHSD Working Paper No. 2014-19. Population Association of America annual meeting.

Krivošić, S. (1981), Zagreb i njegovo stanovništvo od najstarijih vremena do sredine XIX. stoljeća. Zagreb: JAZU (Građa za gospodarsku povijest Hrvatske, knjiga 19). 
Maas, I., i sur. (2002), HISCO: Historical International Standard Classification of Occupations. 1st edn. Leuven, Belgija: Leuven University Press.

Majetić, F. (2015), Zagreb u postindustrijsko doba. Zagreb: Institut društvenih znanosti Ivo Pilar.

Mols, R. (1972) ,Population in Europe, 1500-1700. London: HarperCollins Distribution Services.

Nejašmić, I. (1994), Doseljavanje u Zagreb, Geografski horizont, 40(2), str. 61-72.

Peršić, N. (1935), Prirast i kretanje gradskog stanovništva s naročitim obzirom na Grad Zagreb. Zagreb: Tisak i naklada knjižare St.Kugli.

Statistički godišnjak Zagreba (1955), Zagreb: Grad Zagreb.

Stipetić, V. (2013), Povijest hrvatske ekonomske misli: (1848.-1968.) : knjiga druga. Zagreb: Ekonomski fakultet Zagreb.

Szabo, A. (1984), Regionalno porijeklo i socijalna struktura stanovništva grada Zagreba između 1880-1910. godine, Radovi : Radovi Zavoda za hrvatsku povijest Filozofskoga fakulteta Sveučilišta u Zagrebu, 17(1), str. 101-120.

Theien, I. (2009), Food rationing during World War two: a special case of sustainable consumption?, Anthropology of food, S5.

Weeks, J. R. (2015), Population: An Introduction to Concepts and Issues. 12 edition. Boston, MA: Wadsworth Publishing.

Wertheimer-Baletić, A. (1996), Specifičnosti demografskog razvitka u Hrvatskoj i njegove socio-ekonomske implikacije. Revija za socijalnu politiku (3-4), str. 251258.

Wertheimer-Baletić, A. (1978), Ekonomska aktivnost stanovništva - demografski aspekti. Zagreb: Školska knjiga.

Wertheimer-Baletić, A. (1993), Stanovništvo Vukovara i vukovarskoga kraja. Zagreb: Globus.

Wertheimer-Baletić, A. (1999), Stanovništvo i razvoj. Zagreb: Mate.

Žuljić, S. (1981) Razvoj sistema centara na prostoru SR Hrvatske. U: Prilozi izgradnji naše prostorne teorije, II. (ur. Ivan Krešić, Juraj Padjen i Stanko Žuljić). Zagreb: Ekonomski institut - Zagreb. 


\section{Summary}

\section{The Population of the City of Zagreb Immediately Before and After World War II According to Consumer Registration Forms}

The population of the City of Zagreb faced significant changes in major economic, political and social processes in the first part of the $20^{\text {th }}$ century. The changes taking place in this period, with the pinnacle around World War II, changed the fundamental economic and social paradigm, thus affecting many aspects of demographic behaviour. The objective of this paper is to study major demographic and socioeconomic changes having affected the population of the City of Zagreb in the period between 1931 and immediately after World War II, with respect to the earlier historical circumstances. We have based our analysis on the historical source named Consumer Registration Forms. Consumer Registration Forms were an official document used with the purpose of rationalising consumption in the turbulent times around World War II. They contain information on individual level and in part on household level, depending on the type of registration form. There are two types of these forms: one that began to be distributed in January 1941, and another that began to be distributed in late August 1945. With due respect, no significant political connotations were reported in the first phase of distribution in January 1941; the forms were used for the purchase of basic products, such as food, medicines, energy, etc. We may therefore assume that the coverage of the population with Consumer Registration Forms is comparable with the census. Furthermore, the sheer volume of the Consumer Registration Forms suggests high coverage.

The analysis consists of several descriptive findings since, despite of our best knowledge and effort, we have found no comparable research on this topic. We began with estimating the total population of the City of Zagreb in the months preceding World War II, and in the months following it. We furthermore estimated other basic demographic indicators, including age-and-sex structure, mean age, sex ratio, and others. The analysis showed major imbalance in the age-and-sex structure in the young population as an aftermath of the war.

Our results suggest that there exist major gender differences in the analysed variables. Clear gender distinction exists in the indicators on economic activity - women tend to have significantly lower activity in all age groups, excluding the youngest one analysed. The specific background explains this exception - young women used the model of home servants as one of the main pathways in obtaining economic and social independence. The majority of these women arrived in the years preceding, as immigrants from the neighbouring counties due to having become excess workforce in disintegrated agrarian economies. Such model of home servants was common across Europe in the period between the $17^{\text {th }}$ and the $20^{\text {th }}$ centuries. Family and household structure showed a rather heterogeneous distribution. A relatively high share of single households is expected due to continuous and high immigration in the previous decade. Heterogeneous population structure in pre-war Zagreb presents a scientifically interesting period and object of interest. We suggest several ideas for further research of this topic.

Keywords: population of the City of Zagreb; socio-economic structure; family and household structure; war-conditioned age-and-sex structure. 
